\title{
Efficacy of extract antibacterial flower Rosella flower (Hibiscus sabdariffa Linn) against Streptococcus sanguis
}

\author{
Durotun Nafisa, Warta Dewi, Emma Rachmawati \\ Department of Oral Biology Faculty of Dentistry Universitas Padjadjaran
}

\begin{abstract}
Introduction: Rosella is well known as health drink that contains anti bacterial compounds. The purpose of this research is to examine the anti bacterial potential of rosella calyx ethanol extract towards Streptococcus sanguis. Methods: Streptococcus sanguis was obtained from students' saliva in the clinic of the Faculty of Dentistry, Universitas Padjadjaran. It was cultured in blood agar and incubated for 18 to 24 hours at $37^{\circ} \mathrm{C}$ in a facultative anaerobic environment. Streptococcus sanguis was isolated based on the characteristics of the colonies formed, Gram staining, inulin and rafinose fermentation tests. The anti bacterial test was performed using agar diffusion method (Kirby Bauer Method) by making agar holes in the agar and filling them with rosella extract with concentrations at $0.20 \mathrm{~g} / \mathrm{ml}, 0.10 \mathrm{~g} / \mathrm{ml}, 0.05$ $\mathrm{g} / \mathrm{ml}$ and $0.025 \mathrm{~g} / \mathrm{ml}$. Results: The results of this research show that there was anti bacterial activity from the ethanol extract of rosella calyx with the inhibition zones of $19.85 \mathrm{~mm}, 12.05 \mathrm{~mm}, 8.45 \mathrm{~mm}$ and $3.65 \mathrm{~mm}$ under rosellas's extract's concentration of at $0.20 \mathrm{~g} / \mathrm{ml}, 0.10 \mathrm{~g} / \mathrm{ml}, 0.05 \mathrm{~g} / \mathrm{ml}$ and $0.025 \mathrm{~g} / \mathrm{ml}$ respectively. Conclusion: The conclusion of this research is rosella calyx ethanol extract has the greatest anti bacterial activity at concentration $0.20 \mathrm{~g} / \mathrm{ml}$.
\end{abstract}

Keywords: Ethanol extract of Rosella calyx, Streptococcus sanguis

\section{INTRODUCTION}

Rosella is an annual tropical plant, scattered all over the world with the Latin name Hibiscus sabdariffa Linn that is so popular as a health drink in the form of tea. Almost all parts of this plant can be utilized to complement the needs of life ranging from leaves, petals, seeds or roots used for processed foods and beverages and as herbal medicine. The part of the plant that is often used is the petals. ${ }^{1}$

Roselle petals contain chemicals such as flavonoids, saponins, tannins, anthocyanins (red substances), polyphenolic alkaloids and terpenoids.2-4. The use of rosella as an herbal remedy is used for various purposes such as anti septic, fever, hypertension, canker sores and to treat an abscess 1.5 Flavonoids, saponins and tannins are compounds that have anti-bacterial activity, $2,3,6$ proven saponin in the diet can inhibit the growth of some gram-positive bacteria such as Staphylococcus aureus.2,3,6,7 Concentrations of $20 \mathrm{mg} / \mathrm{ml}, 10 \mathrm{mg} / \mathrm{ml}, 5 \mathrm{mg} / \mathrm{ml}, 2.5 \mathrm{mg} /$ $\mathrm{ml}$ methanol extract of rosella flower petals can produce an average inhibitory area of $0.00 \mathrm{~mm}$ to $0.36 \mathrm{~mm}$ using Staphylococcus aureus 4 The result of ethanol extract test with concentration of $0.20 \mathrm{~g}$ / ml on Escherichia coli bacteria, Salmonella typhi and Staphylococcus aureus resulted in inhibitory diameter of $27.8 \mathrm{~mm}, 30.8 \mathrm{~mm}$, and $27.8 \mathrm{~mm}^{2}$ 
Staphylococcus aureus is a gram-positive coccus bacteria that is a normal flora of the oral cavity. Other bacteria that are normal flora of the oral cavity including gram-positive coccid bacteria are Streptococcus sanguis. This bacterium is a pioneering bacterium of cariogenic dental plaque that can cause caries, or disease in periodontal tissue , 8 therefore the amount of Streptococcus sanguis in the oral cavity must be controlled or reduced by mechanical means or in combination with chemicals such as the use of mouthwash. ${ }^{8}$

Antibacterial test of roselle flower petal extract on gram positive bacteria such as Staphylococcus aureus have been done,2-4,6but the antibacterial effect of roselle petals with the same concentration as Rostinawati $0.20 \mathrm{~g} / \mathrm{ml}$ against Streptococcus sanguis which has properties similar to Staphylococcus aureus that includes normal flora of the oral cavity and gram-positive coccor bacteria has not been tested.

Based on the above description, the researcher is interested to test the antibacterial power of rosella petal extract on Streptococcus sanguis with concentration of $0.20 \mathrm{~g} / \mathrm{ml}$ and some lower concentrations of $0.10 \mathrm{~g} / \mathrm{ml}, 0.05 \mathrm{~g}$ / $\mathrm{ml}$ and $0.025 \mathrm{~g} \mathrm{/} \mathrm{ml}$, which is thought to have several active components that are chemical and have anti-bacterial power, the smaller the side effects that can be caused. The objective of this study was to prove the effectiveness of rosella petal antibody against Streptococcus sanguis by determining the inhibitory area of concentration $0.20 \mathrm{~g} / \mathrm{ml}, 0.10 \mathrm{~g} / \mathrm{ml}, 0.05 \mathrm{~g} / \mathrm{ml}$ and $0.025 \mathrm{~g}$ / $\mathrm{ml}$.

\section{METHODS}

Simplicia rosella flower petals as much as $200 \mathrm{~g}$ mashed, then soaked by using ethanol solvent in a closed container called a maserator. This immersion is done for $3 \times 24$ hours by using $95 \%$ ethanol liquid and every day the solvent is replaced with a new one. After the resulting maserate and extract evaporated with a rotary evaporator until obtained a more viscous extract. ${ }^{9,10}$

Test bacteria were obtained from researchers' saliva. Saliva was collected in a sterile petri dish, then with a sterile saline oes was transferred as much as $0.1 \mathrm{ml}$ to be inoculated on the agar plate medium to use the rectal technique. The inoculated medium is then fed into the eksikator with burning candles and wet cotton to obtain anaerobic facultative atmosphere, subsequently incubating at $37^{\circ} \mathrm{C}$ for 18 to 24 hours .

The medium that has been inoculated saliva and incubated for 18 to 24 hours, on the blood agar plate there is a bacterial colony showing a greenish-colored a-hemolysis reaction allegedly as a class of Streptococcus sp. then do the previous gram painting on the petri dish marked with a marker, then check under the microscope, if obtained results in accordance with the characteristics of Streptococcus sp. then test the identification of the related bacteria through carbohydrate fermentation test using inulin and rafinose medium .

The results of a new carbohydrate fermentation test were obtained after ingressing the inulin and rafinose seeding medium planted with suspension of test bacteria. The medium containing the bacteria is fed into the incubator at $370 \mathrm{C}$ for 18 to 24 hours, if the positive inulin fermentation result is characterized by the inulin color change from red to yellow and the result of a negative rafinose fermentation test showing the red fixed medium results, which can be ascertained that the bacterium is Streptococcus sanguis. ${ }^{11}$

Antibacterial test of roselle flower petal extract was done by using diffusion method. The diffusion method was used to determine how much the inhibitory diameter resulted from concentrations of $0.20 \mathrm{~g} / \mathrm{ml}, 0.10 \mathrm{~g} / \mathrm{ml}, 0.05$ $\mathrm{g} / \mathrm{ml}$ and $0.025 \mathrm{~g} / \mathrm{ml}$, respectively based on a preliminary study done by Rostinawati. ${ }^{2}$ Plant the Streptococcus sanguis on a petri dish using a tightfitting sequence method. Mark $0.20 \mathrm{~g} / \mathrm{ml}, 0.10 \mathrm{~g}$ / $\mathrm{ml}, 0.05 \mathrm{~g} / \mathrm{ml}, 0.025 \mathrm{~g} / \mathrm{ml}$ and $\mathrm{K}$ (control) on the petri dish. Create a $10 \mathrm{~mm}$ diameter hole in the blood that the Streptococcus sanguis planted. Enter a $2 \mathrm{ml}$ solution of roselle petal extract with concentration $0.20 \mathrm{~g} / \mathrm{ml}, 0.10 \mathrm{~g} / \mathrm{ml}, 0.05 \mathrm{~g}$ $/ \mathrm{ml}, 0.025 \mathrm{~g} / \mathrm{ml}$ and sterile aquades used as control.

Medium grown with Streptococcus sanguis was incubated at $37^{\circ} \mathrm{C}$ for 18 to 24 hours. Observe the growth of bacteria to see whether there is an inhibitory area around the hole with the formation of clear areas indicating that the 
extract of roselle flower petals have anti bacterial activity. This research is repeated twice.

\section{RESULTS}

The extract result of $200 \mathrm{~g}$ of simplicia roselle petals extracted was obtained extract condensation weighing $133.95 \mathrm{~g}$ with yield of $66.95 \%$ ( $\mathrm{w} / \mathrm{w}$ ). The incubation of blood agar plates previously inoculated with saliva of $0.1 \mathrm{ml}$ for 18 to 24 hours with $370 \mathrm{C}$ temperature resulted in the growth of various bacteria, but there were some dominant colonies that grew with greenish areas around the colony showing a pict ure of hemodigestion which indicated as Oral-type hepatic streptococcus a-hemolysis.

Microscopic examination using 100 times magnification previously done by gram staining showed a gram-positive gram-colored brown image with long-to-medium chain formations .

The results of the eleven carbohydrate test of colony suspected as oral Streptococcus using inulin showed a change in one culture (no.8) inulin from red to yellow which means it can ferment inulin carbohydrates and rafinose test showed no change, the culture remained red which means no can ferment raffinose carbohydrates. The result of the reaction shows that the suspected colony is Streptococcus sanguis .

Diameter of the resistor area on the blood agar plate after administration of ethanol extract of roselle petals with concentration of $0.20 \mathrm{~g} / \mathrm{ml}$, $0.10 \mathrm{~g} / \mathrm{ml}, 0.05 \mathrm{~g} / \mathrm{ml}, 0.025 \mathrm{~g} / \mathrm{ml}$ and sterile aquades (control) on 10 samples of Streptococcus sanguis with two repetitions can be seen in table 1. The results of this study show that there is a resistor area around the pit plong whereas in the aquades are used as a control not visible resistor area. It proves that ethanol extract rosella petals have anti-bacterial compounds that can inhibit the growth of Streptococcus sanguis.Based on table 1 it is found that the mean diameter of the inhibition area of ethanol extract of roselle petals on Streptococcus sanguis is formed at concentrations of $0.20 \mathrm{~g} / \mathrm{ml}, 0.10 \mathrm{~g} / \mathrm{ml}, 0.05 \mathrm{~g}$ $/ \mathrm{ml}$ and $0.025 \mathrm{~g} \mathrm{/} \mathrm{ml} \mathrm{respectively} \mathrm{of} 19.85 \mathrm{~mm}$, $12.05 \mathrm{~mm}, 8.45 \mathrm{~mm}$ and $3.65 \mathrm{~mm}$, whereas in sterile aquades are not formed $(0 \mathrm{~mm})$.

This shows that the average diameter of inhibition area of ethanol extract of the largest roselle petals is at concentration $0.20 \mathrm{~g} / \mathrm{ml}$ $(19.85 \mathrm{~mm})$ while the smallest is at concentration of $0.025 \mathrm{~g} / \mathrm{ml}$ with inhibitory diameter of 3.65 $\mathrm{mm}$. The data in table 1 were analyzed by using
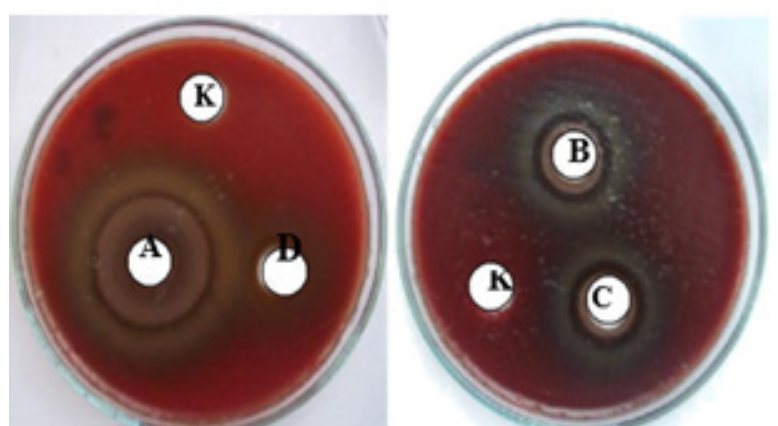

Picure 1 Area of Inhibition Concentration A $(0.20 \mathrm{~g} / \mathrm{ml})$, B $(0.10 \mathrm{~g} / \mathrm{ml}), \mathrm{C}(0.05 \mathrm{~g} / \mathrm{ml}), \mathrm{D}(0.025 \mathrm{~g} / \mathrm{ml})$ and $\mathrm{K}$ (control) extract of roselle petals on Streptococcus sanguis

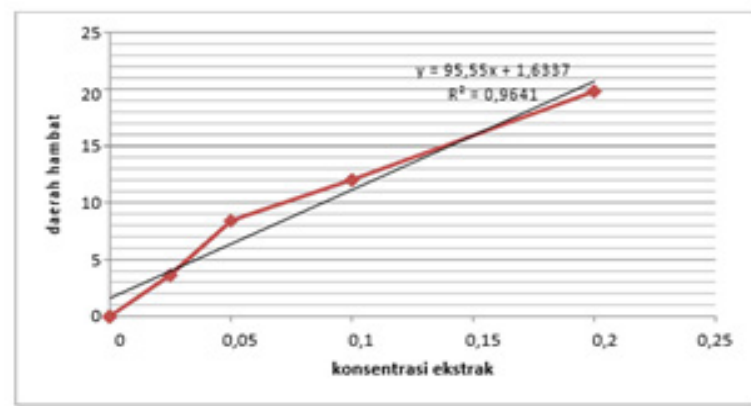

Picture 2 Graph of effect of concentration of ethanol extract of roselle petals on the diameter of the inhibitory regions of Strepococcus sanguis growth.

Tabel 1. Average area of inhibition of roselle petal extract on Streptococcus sanguis

\begin{tabular}{cccccc}
\hline Concentration & $0.20 \mathrm{~g} / \mathrm{ml}$ & $0.10 \mathrm{~g} / \mathrm{ml}$ & $0.05 \mathrm{~g} / \mathrm{ml}$ & $0.025 \mathrm{~g} / \mathrm{ml}$ & Kontrol \\
\hline Rata-rata luas daerah hambat & 19.85 & 12.05 & 8.45 & 3.65 & 0 \\
\hline
\end{tabular}

Table 2. Anova Statistic Results from Average resistor area

\begin{tabular}{lllllllll}
\hline & & FD & TQ & AQ & F & Signifikan F & F tabel & a \\
\hline Regretion & 1 & & 228.2451 & 228.2451 & 80.51031 & 0.002922 & 10.12796 & 0.05 \\
Balance & 3 & 8.504938 & 2.834979 & & & & \\
\hline Total & 4 & 236.75 & & & & \\
\hline
\end{tabular}

Keterangan : $\mathrm{TQ}$ : total quadrant $\mathrm{FD}$ : Freedom Degree $\mathrm{AQ}$ : Average quadrant $\mathrm{F}: \mathrm{F}$ hitung 
anova to know the difference of effectiveness of anti bacterial power average concentration of ethanol extract of rosella petals on Streptococcus sanguis and processed using Microsoft exel is as follows:

The result of the calculation using Anova statistic shows that the ethanol extract of rosella flower petals have different effect on each concentration on bacterial growth as evidenced from $\mathrm{F}$ count (80.51031) greater than $\mathrm{F}$ table $(10.12796)$, Ho is not acceptable at significant level $\alpha=0.05$.

\section{DISCUSSION}

This research was carried out by antibacterial activity test of ethanol extract of roselle petals at His concentration of $0.20 \mathrm{~g} / \mathrm{ml}$, . The advantages of the diffusion method are relatively simple, inexpensive and often used when adequate laboratory facilities are not available and the time required is shorter and the desired results can be interpreted clearly 12 The disadvantages of this method are influenced by many factors besides the interactions between drugs and bacteria (eg seed, diffusion, molecular size and stability of the drug) and can not determine whether a drug is bactericidal and bacteriostatic so that further research is needed by finding the minimum inhibitory concentration for the extract to be used .12

The ethanol extract of roselle petals used in this study was $133.95 \mathrm{~g}$ with a yield of $66.95 \%(\mathrm{w} / \mathrm{w}$ ) tested on Streptococcus sanguis, while the extract concentration used was $0.2 \mathrm{~g} / \mathrm{ml}, 0.1 \mathrm{~g} / \mathrm{ml}$, $0.05 \mathrm{~g} / \mathrm{ml}$ and $0.025 \mathrm{~g} / \mathrm{ml}$ based on previous research conducted by Rostinawati 2 against Escherichia coli test bacteria, Salmonella typhi and Staphylococcus aureus with concentrations of $0.20 \mathrm{~g} / \mathrm{ml}$ also resulting in inhibitory diameter of $27.8 \mathrm{~mm}, 30.8 \mathrm{~mm}$ and $27.8 \mathrm{~mm}$, respectively. ${ }^{2}$

Anti-bacterial activity test results showed that rosella flower has activity as anti bacterium. Proven by using diffusion method, the average diameter of inhibitory area is $19.85 \mathrm{~mm}, 12.05$ $\mathrm{mm}, 8.45 \mathrm{~mm}$ and $3.65 \mathrm{~mm}$ with concentration of $0.20 \mathrm{~g} / \mathrm{ml}, 0.10 \mathrm{~g} / \mathrm{ml}, 0.05 \mathrm{~g} / \mathrm{ml}$ and $0.025 \mathrm{~g} /$ $\mathrm{ml}$ respectively Strepococcus sanguis. The widest diameter of the inhibitory area is at concentration $0.20 \mathrm{~g} / \mathrm{ml}$ of $19.85 \mathrm{~mm}$ and the smallest at a concentration of $0.025 \mathrm{~g} / \mathrm{ml}$ of $3.65 \mathrm{~mm}$. Based on the results of phytochemical screening of ethanol extract rosella petals containing saponin compounds, tannins and flavonoids that have antibacterial activity .2, Saponin, an active substance that can increase membrane permeability resulting in cell hemolysis, when saponins interact with bacterial cells, the bacteria will break or lysis. Flavonoids are a group of phenol compounds that have a tendency to bind proteins, thus interfering with bacterial cell metabolism processes. Tannins, in low concentrations are able to inhibit bacterial growth, whereas at high concentrations, tannins work as anti-bacterial by coagulating or agglomerating protoplasm bacteria to form bonds which is stable with bacterial proteins.

Based on the results of anti-bacterial tests on Streptococcus sanguis ethanol extract rosella flower petals form an inhibitory area against the growth of test bacteria. Data of mean diameter of growth area of Strepococcus sanguis in each concentration showed that the higher concentration of ethanol extract of roselle petals, the greater the diameter of the inhibitory area produced (Figure 2). This may be due to increased levels of chemical components that are antibacterial in the ethanol extract of roselle petals at a greater concentration compared to smaller concentrations

Based on the Clinical and Laboratory Standards Institute (CSLI), the inhibition areas produced at concentrations of $0.10 \mathrm{~g} / \mathrm{ml}, 0.05 \mathrm{~g}$ $/ \mathrm{ml}$ and $0.025 \mathrm{~g} / \mathrm{ml}$ were classified as resistant bacteria because the resulting inhibitory area was less than $12 \mathrm{~mm}$ ie $3.65 \mathrm{~mm}, \mathrm{~mm}, 12.05 \mathrm{~mm}$ while at concentration $0.20 \mathrm{~g} / \mathrm{ml}$ including bacteria sensitive to ethanol extract rosella flower petals because the area of its inhibition is more than 18 $\mathrm{mm}$ that is equal to $19.85 \mathrm{~mm} .{ }^{13}$

The result of statistic calculation using Anova from the mean data of diemeter inhibition showed that there was different effect from each concentration of rosella flower petal extract on the growth of Streptococcus sanguis ( $F$ count (80.51031) greater than $\mathrm{F}$ table (10.12796)).

The results of data analysis of diameter of the inhibition area of Strepococcus sanguis growth at concentration $0.20 \mathrm{~g} / \mathrm{ml}, 0.10 \mathrm{~g} / \mathrm{ml}, 0.05$ $\mathrm{g} / \mathrm{ml}$ and $0.025 \mathrm{~g} / \mathrm{ml}$ of rosella flower extract yielded inhibitory area $19.85 \mathrm{~mm}, 12.05 \mathrm{~mm}$, $8.45 \mathrm{~mm}$ and $3.65 \mathrm{~mm}$. These results show that 
the ethanol extract of roselle petals has an antibacterial effect on Strepococcus sanguis.

\section{CONCLUSION}

Based on the results of the study, rosella flower petal extract has anti-bacterial power against Streptococcus sanguis growth. The extract of roselle petals can inhibit the growth of Streptococcus sanguis with the inhibitory areas of $19.85 \mathrm{~mm}, 12.05 \mathrm{~mm}, 8.45 \mathrm{~mm}$ and $3.65 \mathrm{~mm}$ of concentration $0.20 \mathrm{~g} / \mathrm{ml}, 0.10 \mathrm{~g} / \mathrm{ml}, 0.05 \mathrm{~g} / \mathrm{ml}$ and $0.025 \mathrm{~g} / \mathrm{ml}$.

\section{ACKNOWLEDGEMENT}

Acknowledgments or explicit statements regarding financial support, employment relationships, resource ownership, expert consultation or patent registration, grants or other funding schemes by specifying the individual or institution concerned if any.

\section{REFERENCES}

1. Mardiah A, Rahayu AR, Wicaksono, Sawarni. Budi Daya dan Pengolahan Rosela Si Merah Segudang Manfaat. Jakarta: Agro Media. 2009. 13-28 pp.

2. Rostinawati T. Aktivitas antibakteri ekstrak etanol bunga rosela (Hibiscus sabdariffa L.) Terhadap Escherichia coli, Salmonella typhi dan Staphylococcus aureus dengan metode difusi agar. Jatinangor: Fakultas Farmasi Universitas Padjadjaran. 2009. http:// pustaka.unpad.ac.id/archives/70227/

3. Zuhrotun AR, Hendriani, Kusuma SAF. Pemanfaatan ekstrak air kelopak bunga rosella (Hibiscus sabdriffa. L) asal kabupaten bandung barat sebagai antiinfeksi terhadap beberapa genus bakteri Staphylococcus. Lembaga Penelitian Dan Pengabdian Kepada Masyarakat Universitas Padjadjaran. 2009 http://pustaka.unpad.ac.id/archives/88409/

4. Adebisi O, Ojokoh OA. Antimicrobial activities of green and red calyx extracts of hibiscus sabdariffa on some microorganisms. J
Agriculture Biological Sci. 2011;2(2):038-42.

5. James AD. Handbook of energy crops. 1983. Available online at: http://www.hort. purdue.edu/newcrop/duke_energy/hibiscus_ sabdariffa.html (diakses 3 maret 2012)

6. Olaleye MT. Cytotoxicity and antibacterial activity of methanolic extract of hibiscus sabdariffa. Journal of Medicinal Plants Research. 2007;1(1):009-013.

7. Cheeke PR. Actual and potential applications of Yucca schidigera and Quillaja saponaria saponins in human and animal nutrition. Department of Animal Sciences, Oregon State University, Corvallis 97331. 2000.

8. Samanarayake L. Essential Microbiology for Dentistry 3th ed. Churchill Livingstone. 2006; 225, 261, 270, 278, 289 pp.

9. Zuhrotun A, Hendriani R, Kusuma SAF. Pemanfaatan ekstrak air kelopak bunga rosella (Hibiscus sabdriffa. L) asal kabupaten bandung barat sebagai antiinfeksi terhadap beberapa genus bakteri Staphylococcus. Lembaga Penelitian Dan Pengabdian Kepada Masyarakat Universitas Padjadjaran. 2009. http://pustaka.unpad.ac.id/archives/88409/

10. Iskandar Y. Zuhrotun A. Panduan Praktikum Farmasi Bahan Alam. Jatinangor. Laboratorium farmasi bahan alam fakultas farmasi universitas padjadjaran jatinangor. 2011. 7-9 pp.

11. Kilian M, Mikkelsen L, Henrichsen J. Taxonomic study of viridans streptococci: description of Streptococcus gordonii sp. Nov. And emended descriptions of Streptococcus sanguis (white and niven 1946), Streptococcus oralis (bridge and sneath 1982), and Streptococcus mitis (andrewes and horder 1906). International Journal Of Systematic Bacteriology. Oct. 1989;471484

12. Mawaddah R. Kajian Hasil Riset Potensi Antimikroba Alami Dan Aplikasinya Dalam Bahan Pangan Di Pusat Informasi Teknologi Pertanian Fateta IPB. Bogor: IPB. 2008. 10 pp.

13. Poeloengan $M$. Praptiwi. Uji aktivitas antibakteri ekstrak kulit buah manggis (garcinia mangostana linn). Med Litbang Kes. 2010;22(2):1-7. 
